Удк 811.161.2'373.45+070

\title{
Е. Е. Мінкевич,
}

ст. викладач кафедри загального та слов'янського мовознавства філологічного факультету

Одеського національного університету імені І. І. Мечникова, Французький бульвар, 24 / 26, м. Одеса, 65058, Україна, тел.: +3800487760442,

movoznavstvo98@gmail.com 


\section{СЕМАНТИЗАЦІЯ НЕОЗАПОЗИЧЕНЬ У ТЕКСТАХ УКРАЇНСЬКИХ ЗМІ НА ПОЧАТКОВОМУ ЕТАПІ ЇХНЬОї АДАПТАЦІї}

В статті розглянуто семантизацію нових запозичень (неозапозичень) у текстах українських ЗМІ в 2016 - 2017 pp. Актуальність розгляду обраної проблеми випливає з потужного зростання потоку запозичень в сучасну українську мову та активного відображення змін у лексиці сучасних 3МI. Об'єктом дослідження стали нові запозичення, а його предметом - адаптація зазначених лексем до української мови. Метою статті є опис початкового етапу семантичної адаптації цих слів до лексико-семантичної системи мови, яка їх прийняла, а завданнями - аналіз семантизації новітніх запозичень у тексті, їхнього значення та походження.

Ключові слова: запозичення, неологізми, адаптація запозичень, ЗМІ.

$\mathrm{X}$

оч дослідження процесів адаптації сучасних запозичень протягом останнього часу неодноразово ставали предметом уваги дослідників $[1 ; 2 ; 3 ; 6]$, сучасні 3МI, що відбивають живий стан української мови та іï динаміку, дають багатий матеріал для спостережень над новітніми запозиченнями, зокрема над їхнім пристосуванням до системи мови-реципієнта. 3 цього випливає актуальність розгляду обраної теми. Об'єктом дослідження стали нові запозичення, а його предметом - адаптація зазначених лексем до української мови. Метою статті $\epsilon$ опис початкового етапу семантичної адаптації цих слів до лексико-семантичної системи мови, яка їх прийняла, а завданнями - аналіз семантизації новітніх запозичень у тексті, їхнього значення та походження.

Власне кажучи, запозичення, розглянуті в цій статті, знаходяться на початкових етапах входження до складу мови-реципієнта. В схемі п’яти етапів засвоєння запозичень, запропонованій Л. П. Крисіним [5], ці слова знаходяться на першому та другому етапах: йдеться про вживання іншомовного слова у тексті „в его исконной орфографической (а в устной речи - фонетической) и грамматической форме, 
без транслитерации и транскрипции, в качестве своеобразного вкрапления” (перший етап), а також про пристосування його „к системе заимствующего языка: транслитерация или транскрипция (roast-beef превращается в ростбиф, affectation - в аффектацию и т. д.)" (другий етап).

Адаптація форми нових запозичень у мові-реципієнті розпочинається 3 транслітерації - переведення у властиву цій мові графічну систему; адаптація ж змістового аспекту новітнього запозичення на найпершому етапі полягає у семантизації слова, тобто поясненні його значення в тексті, де воно вжите [див.: 7, с. 85-99]. Надалі семантична адаптація запозичення полягатиме вже у закріпленні за ним певного значення - саме того, у якому воно і з'явилося у мові-реципієнті, чи, може, пізнішого переносного значення, яке виникло вже на основі метафоричного переосмислення. Розглянемо ці процеси на прикладах запозичень кейс та тюнінг: перше 3 них $є$ новим запозиченням, а друге, запозичене принаймні років десять тому, за цей час розвинуло ще й переносні значення.

Якщо запозичене кількадесят років тому з англійської слово кейс „Плаский шкіряний чемоданчик з кодовим замком” (синонім дипломam) пов'язане з case „коробка, футляр, сумка”, то нове запозичення кейс „випадок із практики” походить від омоніма case „випадок, ситуація, справа". Попервах зустрічаємо пояснення значення цього нещодавнього запозичення: Замість моніторингу краӥн вони хочуть „моніторинг кейсів”, тобто випадків [13, 07.10. 2016]. Проте в інших випадках вживання слова саме в такому значенні вже не коментується: „Справа Артамоновӧ” стала кейсом, з якого варто розпочинати вивчення методів протидії академічній недоброчесності в Україні $[9,9.09 .2016]$.

Тюнінг (< англ. tuning „налаштування”, „доопрацювання”), запозичене спочатку на позначення змін в автомобілі, спрямованих на поліпшення його властивостей, з часом стало вживатися й у значенні „зовнішні зміни, спрямовані на прикрашання ситуації, а не на іiі покращення": Питання в тому, чи розуміють вони, щзо за умови фактичного тюнінгу старих практик адміністрування і транслювання 
змістів, які їм зосталися від одіозного попередника, якісних і позитивних для украӥнської України змін не станеться? [12, 2.09. 2016]; Отже, говорити навіть про тюнінг сталінської костоломної системи, чиї колеса ритмічно працювали всі 25 років украӥнської незалежності, особливого сенсу немає [98, 9.09. 2016]. Як видно з наведених прикладів уживання, слово змінило своє значення шляхом метафори: „техніка” > „політика”. Цікавим є й приклад перенесення значення 3 донорської зони „техніка” в реципієнтну зону „людина”: „Тюнінг” тіла - нова послуга для чоловіків (2013, URL: video.bigmir.net/).

Дослідники неодноразово зазначали, що на сьогодні запозичуються переважно слова $з$ англійської мови. Це підтверджує і наш матеріал. Проте наявні серед неозапозичень і такі, що прийшли з інших мов. Порівняно з англіцизмами вони нечисленні та здебільшого $є$ екзотизмами, що номінують етноспецифічні реалії і вживаються у тексті з типовою для екзотизмів функцією вказівки на особливості зображуваної дійсності. Це можуть бути реалії політичного характеру: 3 жовтня парламент Естонії (Рійгікогу) знову збереться для виборів нового президента [9, 1.10. 2016]; заголовок Іран: рахбар, баржам i вибори [9, 12.03. 2017], пор. далі у тексті: Над усіма політичними інтригами в Ірані стоїть Верховний лідер (рахбар) Алі Хаменеї. < ..> Останні жодним словом не прохопилися про намір скасувати „баржам” (іран. акронім для Спільного всеосяжного плану дій). < ..> „Пан Рухані обіияв, щзо всі санкиії будуть зняті після укладення баржаму, однак люди не побачили змін на своїх столах. Тож чи було вирішене питання рецесії $і$ безробіття?" - запитав Раїсі; Сьогодні естелад (естелада - прапор, у якому поєднані каталонські та кубинські елементи і який став знаменом тих, хто прагне незалежності свого краю) у Каталонії менше, ніж раніше [12, 14.01.2017]. Пор. також назву народності: Ідеться про перерозподіл земель, які для одних груп населення є полями, а для інших пасовиськами для худоби. Все че виливається в терор, до якого останнім часом вдаються фулані - етнічна група скотарів, які населяють північно-західні регіони Нігеріï $[12,10.01 .2017]$. Неоекзотизми фаду та фадишти номінують реалії португальської музичної культури: Про часи диктатури 
говорять як про період стабільності, й тому деякі португальијі на честь Салазара складають навіть тужливі пісні - фаду. Зрештою, фадишти - так називаються виконавиі иього музичного жанру постійно торкаються теми минулого та втраченого, щзо виражає поняття saudade (невимовна туга, ностальгія, сум) [12, 16.01. 2017).

Втім, окремі запозичення не $з$ англійської мови номінують реалії, що поступово проникають в інші культури на побутовому рівні, не втрачаючи поки що своєї етноспецифічності: $У$ Вашингтоні найбільша спільнота ефіопиів за межами Африки, закладів зі своєю начіональною кухнею вони відкрили дуже багато. Овочеві та м'ясні страви тут переважно гострі, їх подають на инджері - великому млиниі із сірого борошна $[10,16.06$. 2017]; Вона - альпіністка, відома спортсменка - член збірної Росії з карате, переможниия всеросійських і міжнародних змагань із джиу-джитсу, кобудо (бойового мистецтва володіння холодною зброєю) [9, 17.02. 2017].

Неозапозичення, що супроводжуються у текстах ЗМІ поясненням значення, належать до кількох семантичних груп. Це передусім назви побутових явищ - одягу (буркіні), їжі та пов'язаних з нею понять (мухінга, капкейк, фуд-трак, фудi), книжок (picture book, easy reading), інших побутових реалій (колівінг, mixed-use, altmetall). Історія слова буркіні демонструє перебування лексеми на маргінесі європейських мов: опис його значення й походження представлений в російськомовному джерелі 2011 р. (фр. burqa „паранджа” + бікіні [8]), проте вживання слова 3 поясненням значення в українських ЗМІ припадає на 2016 р. і було актуалізоване забороною (тимчасовою) вживання буркіні у Франції: Державна рада Франиії призупинила дію заборони на буркіні - купальний костюм для мусульманок [13, 26.08. 2016].

Семантизація назв їжі та пов'язаних з нею понять виглядає таким чином: Першого ж дня ми з чоловіком спробували мухінгу - традииійні макарони, перемішані з бобовим борошном, олійкою та овочами: білокачанна капуста, помідори, зелень, інколи туди ще додають морепродукти і обов'язково приправляють традиційним соусом [13, 16.09. 2016]; Із солодощів місиеві полюбляють купувати у кафе маффіни та капкейки, простіше кажучи, кексики із різними кремами 
[10, 16.06. 2017]; Неймовірно популярні фуд-траки, тобто автомобілі-вагончики, де продають, на мій подив, пристойну їжу [10, 16.06. 2017]; Також у вашингтонських закладах майже всюди є happy hour, „щаслива година”. Приблизно з 5 до 7 вечора по буднях пропонують напої та легкі закуски ледь не за півціни. Покликати колег на „геппі аур” і поспілкуватись годинку за келихом вина чи пива лише за \$ 3-5 дуже розповсюджена практика $[10,16.06 .2017]$; Цікаво, щзо в деяких таких мобільних кухнях готують настільки смачно, що місцеві „ффуді" (по-нашому, любителі смачно попоїсти) узагалі полюють на них, слідкуючи за їхніми переміщеннями на спеціальних сайтах чи у сочмережах [10, 16. 06. 2017].

На початковому етапі запозичення можуть мати вигляд іншомовних вкраплень, записуючись латиницею. Пор. опис типів книжок: $\mathrm{Ha}$ сьогодні нам дуже бракує книжок формату picture book, які містять великі ілюстраиії та небагато тексту, поданого великим шрифтом [12, 15.10. 2016]; Також нині шукаємо книжок easy reading для дітей, щзо тільки вчаться читати $[12,15.10 .2016]$.

Деякі неозапозичення на позначення побутових реалій мають певні шанси закріпитись в українській мові, бо позначають важливі тенденції містобудування: Що значить багатофункиіональний комплекс? Для Украӥни такий формат поки що новинка, а ось в Євроnі $і$ США він з кожним роком набирає все більшої популярності. ЦЦе будівлі, де житло, робота, розваги, дозвілля і шопінг знаходяться в межах одного комплексу будівель або одного кварталу в радіусі пімої доступності. Урбаністи ще називають такий підхід до організаиії міського простору „колівінг”, „mixed-use” $i$, концентрація” [10, 2301. 2017]. Колівінг < co- + live + -ing; префікс со- - скорочена форма від лат. com- / con- < cum ,з, разом з" [4, с. 475]; Багато з інноваиій, про які мова, мають на меті покрашити якість життя людини як у великих, так і у малих речах. Одна з них - це конщепція Smart city, розумних міст $[12,13.04$. 2017]. Власне, в останньому випадку маємо не пояснення значення, а лише переклад: поняття Smart city розкриває текст статті. Втім, у багатьох випадках неозапозичення-вкраплення вживаються лише для вказівки на зображення життя в іншій країні, як-от при описі сортування сміття в Німеччині та Швейцарії: С відсік altmetall (старий метал) [9, 19.05. 2017]. 
Представлені серед неозапозичень і назви понять, пов'язані 3 кіно. Це переважно назви досить специфічних жанрів: „Готель Елеон" - спін-офф (продовження, основними дійовими особами якого є персонажі, що раніше фігурували в іншому фільмі) популярного російського сіткому „Кухня” [13, 10.01. 2017]; втім, лексема може вживатися й без семантизації: Він також зазначив, що створення приквела накладає на сиенаристів менше зобов'язань, ніж написання сценарію спін-оффу [9, 16.01. 2017]. Пор. також інші назви жанрів: Гостросюжетна історія боротьби українських підпільників у тридияті роки минулого століття обіияе стати першим вітчизняним Heist movie - стрічкою в особливому кримінальному жанрі „фільмпограбування” [11, 13.02. 2017]; „Heist movies ведуть свій родовід аж від німого кіно. Наскільки я знаю, у иъьому жанрі є щее піджанр „кейпер” - „комедійне пограбування” [11, 13.02.2017]; Слово „квір” символізувало відкидання фемінності / маскулінності та гетеросексуальності / гомосексуальності як фіксованих, незмінних та взаємовиключних категорій і відмову від політик ідентичності, які характеризували ЛГБТ-рух 1970-х років. Сьогодні поняття „квір-кіно” $\underline{\text { ma }}$ „ЛГБТ-кіно ” часто вживаються як синоніми $[13,27.10 .2016]$. Номінативні потреби зумовлюють появу неозапозичень, пов' язаних з особливостями реклами кіно, техніки виконання: Вебізод - ие короткий епізод, призначений для показу в інтернеті, який доповнюе сюжет повночінного фільму або серіалу. Скільки повинен тривати вебізод, що в ньому найважливіме $і$ який серіал ввів моду на цей жанр [11, 4.05. 2017]; Кліп створений з використанням техніки stop-motion, коли відео складається з послідовності кадрів, знятих на фото [10, 8.09. 2016].

Таким чином, семантизація супроводжує новітнє запозичення на початковому етапі його входження до мови-реципієнта. Таке пояснення значення $\epsilon$, з одного боку, сигналом неадаптованості запозичення, а з іншого боку, поштовхом до його засвоєння мовою у майбутньому. Перспективи подальшого дослідження вбачаємо у розгляді особливостей іншомовних слів в момент їх входження в українську мову (семантизація, графічна неадаптованість - передача латиницею). 


\section{Список використаних джерел та літератури}

1. Архипенко Л. М. Іншомовні лексичні запозичення в українській мові: етапи і ступені адаптації (на матеріалі англіцизмів у пресі кінця XX початку XXI ст.) : Автореф. дис. ... на здобуття наук. ступеня канд. філол. наук : 10.02.01 / Л. М. Архипенко. - Х., 2005. - 20 с.

2. Битківська Я. В. Тенденції засвоєння і розвитку семантики англізмів у сучасній українській мові : Автореф. дис. ... на здобуття наук. ступеня канд. філол. наук : 10.02.01 / Я. В. Битківська. - Івано-Франківськ, 2008. - 20 c.

3. Гудима Н. В. Семантична адаптація запозичених лексем у сучасній українській літературній мові / Н. В. Гудима // Наукові праці Кам’янецьПодільського національного університету імені Івана Огієнка. Філологічні науки. - 2013. - Вип. 32(1). - C. 27-31. URL: http://nbuv.gov.ua/UJRN/ Npkpnu fil_2013.

4. Етимологічний словник української мови: В 7 т. / Редкол. О. С. Мельничук (головний ред.) та ін. - К. : Наук. думка, 1985. - Т. 2.

5. Крысин Л. П. Этапы освоения иноязычного слова / Л. П. Крысин // Русский язык в школе. - 1991. - № 2. - С. 75-78.

6. Лисенко О. А. Освоєння німецькомовних запозичень в українській науково-технічній термінології : Автореф. дис. ... на здобуття наук. ступеня канд. філол. наук : 10.02.01 / О. А. Лисенко. - Х., 1999. - 21 с.

7. Мінкевич Е. Е. Прикметникові деривати від новітніх запозичень у сучасних українських ЗМІ / Е. Е. Мінкевич // Слов'янський збірник: 3б. наук. пр. - Чернівці : Букрек, 2016. - Вип. 20. - С. 85-99.

8. Тумовская М. Бикини и буркини - разные цвета одной радуги. Beauty Women (16 февраля 2011). URL: http://wikivisually.com/lang-ru/

9. Дзеркало тижня. URL: http:// gazeta. dt.ua

10. Новое время. URL: http://nv.ua/

11. Телекритика. URL: http://www. telekritika.ua

12. Тиждень. URL: http://tyzhden.ua/ Magazine/

13. Українська правда. URL: http://www.pravda.com.ua/

\section{References}

1. Arkhypenko L. M. Inshomovni leksychni zapozychennya v ukrayins'kiy movi: etapy i stupeni adaptatsiyi (na materiali anhlitsyzmiv u presi kintsya XX- 
pochatku XXI st.) : Avtoref. dys. ... na zdobuttya nauk. stupenya kand. filol. nauk : 10.02.01 / L. M. Arkhypenko. - Kh., 2005. - 20 p.

2. Bytkivs'ka Ya. V. Tendentsiyi zasvoyennya i rozvytku semantyky anhlizmiv u suchasniy ukrayins'kiy movi : Avtoref. dys. ... na zdobuttya nauk. stupenya kand. filol. nauk : 10.02.01 / Ya. V. Bytkivs'ka. - Ivano-Frankivs'k, 2008. $-20 \mathrm{p}$

3. Hudyma N. V. Semantychna adaptatsiya zapozychenykh leksem u suchasniy ukrayins'kiy literaturniy movi / N. V. Hudyma // Naukovi pratsi Kam'yanets'-Podil's'koho natsional'noho universytetu imeni Ivana Ohiyenka. Filolohichni nauky. - 2013. - Vyp. 32(1). - S. 27-31. URL: http://nbuv.gov.ua/ UJRN/Npkpnu_fil_2013.

4. Etymolohichnyy slovnyk ukrayins'koyi movy: V 7 t. / Redkol. O. S. Mel'nychuk (holovnyy red.) ta in. - K. : Nauk. dumka, 1985. - T. 2.

5. Krysin L. P. Etapy osvoeniya inoyazychnogo slova / L. P. Krysin // Russkiy yazyk v shkole. - 1991. - № 2. - P. 75-78.

6. Lysenko O. A. Osvoyennya nimets'komovnykh zapozychen' v ukrayins'kiy naukovo-tekhnichniy terminolohiyi : Avtoref. dys. ... na zdobuttya nauk. stupenya kand. filol. nauk : 10.02.01 / O. A. Lysenko. - Kh., 1999. $-21 \mathrm{p}$.

7. Minkevych E. E. Prykmetnykovi deryvaty vid novitnikh zapozychen' u suchasnykh ukrayins'kykh ZMI / E. E. Minkevych // Slov'yans'kyy zbirnyk: zb. nauk. pr. - Chernivtsi : Bukrek, 2016. - Vyp. 20. - P. 85-99.

8. Tumovskaya M. Bikini i burkini - raznye tsveta odnoy radugi. Beauty Women (16 fevralya 2011). URL: http://wikivisually.com/lang-ru/

9. Dzerkalo tyzhnya. URL: http:// gazeta. dt.ua

10. Novoe vremya. URL: http://nv.ua/

11. Telekrytyka. URL: http://www. telekritika.ua

12. Tyzhden'. URL: http://tyzhden.ua/ Magazine/

13. Ukrayins'ka pravda. URL: http://www.pravda.com.ua/ 


\section{Э. Э. Минкевич}

\section{СЕМАНТИЗАЦИЯ}

НЕОЗАИМСТВОВАНИЙ

В ТЕКСТАХ УКРАИНСКИХ СМИ

В НАЧАЛЬНЫЙ ПЕРИОД ИХ АДАПТАЦИИ

В статье рассматривается семантизация новых заимствований (неозаимствований) в текстах украинских СМИ в 2016-2017 г.г. Актуальность рассмотрения избранной проблемы следует из мощного возрастания потока заимствований в современный украинский язык и активного отражения изменений в лексике языка в современных СМИ. Объектом исследования стали новые заимствования, а его предметом - адаптация указанных лексем к системе украинского языка. Целью статьи является описание начального этапа адаптации этих слов к лексико-семантической системе языка-репициента, а задачами - анализ семантизации новых заимствований в тексте, их значений и происхождения.

Ключевые слова: заимствование, неологизм, адаптация заимствований, СМИ.

\section{E. E. Minkevich,}

Senior Lecturer of General and Slavic Linguistics Department,

Odesa I. I. Mechnikov National University,

24 / 26, Frantsuzky Blvd., Odesa, 65058, Ukraine,

tel.: +3800487760442 ,

movoznavstvo98@gmail.com 


\title{
SEMANTIZATION OF NEODERIVATIONS IN THE TEXTS OF UKRAINIAN MASS MEDIA IN THE INITIAL PERIOD OF THEIR ADAPTATION
}

\begin{abstract}
Summary
The article examines semantization of new derivations (neoderivations) in the texts of Ukrainian mass media in 2016-2017 years. The relevance of the examination of the chosen problem results from the dramatic increase in derivations in modern Ukrainian language and the active reflection of changes in the vocabulary in modern mass media. The object of the research is neoderivations, and its subject is the adaptation of the indicated lexemes to the system of the Ukrainian language. The purpose of the article is the description of the initial period of the adaptation of these words to the lexical-semantic system of the language recipient, and the tasks are the analysis of the semantization of new derivations in the text, their meanings and origin. The article describes meanings of the neoderivations, the appearance of the figurative meaning of the derivation tuning, represents and analyses the explanation of the neoderivations as well as their origin in the texts of mass media.
\end{abstract}

Key words: derivation, neologism, adaptation of the derivations, mass media. Надійила до редакиії 15.07.2017 p. 